\begin{tabular}{|l|l|l||}
\hline \multicolumn{2}{|c|}{ PublisherInfo } \\
\hline \hline PublisherName & $:$ & BioMed Central \\
\hline \hline PublisherLocation & $:$ & London \\
\hline \hline PublisherImprintName & $:$ & BioMed Central \\
\hline \hline
\end{tabular}

\title{
Retroviral link to schizophrenia?
}

\begin{tabular}{|l|l|l||}
\hline \multicolumn{2}{|c||}{ ArticleInfo } \\
\hline \hline ArticleID & $:$ & 4048 \\
\hline \hline ArticleDOI & $:$ & $10.1186 /$ gb-spotlight-20010412-01 \\
\hline \hline ArticleCitationID & $:$ & spotlight-20010412-01 \\
\hline \hline ArticleSequenceNumber & $:$ & 119 \\
\hline \hline ArticleCategory & $:$ & Research news \\
\hline ArticleFirstPage & $:$ & 1 \\
\hline \hline ArticleLastPage & $:$ & 2 \\
\hline \hline & $:$ & RegistrationDate : 2001-04-12 \\
ArticleHistory & $:$ & OnlineDate \\
\hline \hline ArticleCopyright & $:$ & BioMed Central Ltd2001 -04-12 \\
\hline \hline ArticleGrants & $:$ & \\
\hline \hline ArticleContext & $:$ & 130592211 \\
\hline \hline
\end{tabular}


SPIS MedWire

Email: medwire@sciencenow.com

Schizophrenia remains poorly understood, but is almost certainly an umbrella term covering a range of conditions with a number of common symptoms. One possible cause has been identified in the 10 April Proceedings of the National Academy of Sciences.

Håkan Karlsson and colleagues compared cerebrospinal fluid taken from 35 people diagnosed with schizophrenia to that taken from 12 people who were healthy or who had a condition other than schizophrenia. Using molecular markers, they found that $29 \%$ of people with acute schizophrenia and $7 \%$ of those with a chronic form of the disease showed the 'footprint' of a retrovirus from the ' $\mathrm{W}$ ' family of human endogenous retroviruses (HERV-W). The footprint was undetectable in people who did not have schizophrenia.

Robert Yolken, from Johns Hopkins School of Medicine, US, who is one of the authors, said "While a low level of retrovirus expression occurs in most humans, we found an unexpectedly high level of expression in the cerebrospinal fluid from individuals who'd had a recent onset of schizophrenia". Endogenous retroviruses are part of the human genome, having inserted themselves possibly millions of years ago, but the part they play in human disease is just beginning to be understood.

Although no mechanism is discussed for the involvement of retroviral genes in schizophrenia Holken adds, "Our ultimate hope is that we can interfere with the retrovirus by preventing it from becoming active. If we can do that, it may give doctors another method of treating schizophrenia."

\section{References}

1. Karlsson H, Bachmann S, Schröder J, McArthur J, Torrey EF, Yolken RH: Retroviral RNA identified in the cerebrospinal fluids and brains of individuals with schizophrenia. PNAS 2001, 98:4634-4639., [http://www.pnas.org/cgi/content/short/98/8/4634]

2. Johns Hopkins School of Medicine, [http://infonet.welch.jhu.edu/som/]

This PDF file was created after publication. 